\title{
APPLICATION OF SYNTHETIC DNA PROBES OF HUMAN ALPHA SATELLITE CONSENSUS MONOMER FOR DETECTION OF CENTROMERE- INVOLVED CHROMOSOME ABNORMALITIES
}

\author{
Yosuke Kameoka, ${ }^{1}$ Takayasu Date, ${ }^{2}$ and Katsuyuki Hashimoto ${ }^{1}$ \\ ${ }^{1}$ Department of Virology \& Rickettsiology, National Institute of Health, \\ Kamiosaki, Shinagawa-ku, Tokyo 141, Japan \\ ${ }^{2}$ Division of Cancer Research, Medical Research Institute, Kanazawa Medical University, \\ Uchinada-cho, Ishikawa 920-02, Japan
}

\begin{abstract}
Summary We have synthesized the alphoid monomer of $171 \mathrm{bp}$ based on the consensus sequence of human alpha satellite DNA and constructed a clone of dimeric or tetrameric sequence unit. Southern blot analysis using the clone as a probe showed restriction site periodicities in human DNA digested by EcoRI or BamHI. The synthetic consensus unit could detect the alpha repeated centromeric regions of all human chromosomes by fluorescence in situ hybridization. Using the cells having a dicentric $\mathrm{X}$ chromosome, we showed that the two centromeric regions were stained with fluorescent alpha satellite DNA probes. Thus the probe would be useful to detect chromosomal abnormalities such as dicentrics.
\end{abstract}

Key Words alphoid, alpha satellite, centromere, dicentrics, fluorescence in situ hybridization

\section{INTRODUCTION}

In primate genome, the centromeric region of chromosome is dominated by a diverse class of highly repeated DNA, alphoid or alpha satellite sequences. The alpha satellite repeat units are composed of diverse, tandemly reiterated monomer units of $\sim 171$ bp and characterized by particular restriction enzyme periodicities involving multiple monomers referred to as higher-order repeat units (Waye and Willard, 1987; Alexandrov et al., 1988). Analysis of these monomer units of alpha satellite DNA has revealed a certain degree of sequence heterogeneity, which is a basis for chromosome specificity of the alpha satellite DNA family. Despite such heterogeneity within the human alpha satellite repeat units, several attempts have been made to derive a human satellite consensus sequence and to identify evolutionarily conserved sequences within the monomer units (Waye and Willard, 1987; Vissel and Choo, 1987; Willard and Waye, 1987; Alexandrov et al., 1988). The

Received March 5, 1990; revised version received April 13, 1990; Accepted April 25, 1990 
consensus nucleotide sequences were deduced from the sequence data of 153 (Waye and Willard, 1987) and 145 (Vissel and Choo, 1987) monomer units isolated from more than 12 human chromosomes.

Chromosome-specific repetitive DNA markers would be useful to identify individual chromosomes or chromosome regions (Moyzis et al., 1987). Actually the alpha satellite DNA clones have been used for the identification of a certain chromosome sorted by flow cytometry and for cytogenetical analysis of human chromosomes (van Dekken and Bauman, 1988; Dale et al., 1989). The chromosomal distribution in interphase nuclei was also analyzed using a certain chromosomespecific alpha satellite DNA (van Dekken and Bauman, 1988; Meyne and Moyzis, 1989). However, a useful clone which could recognize the centromeric regions of all types of human chromosomes in methaphase and interphase nuclei has to be developed in order to obtain a sufficient signals on chromosomes under a normal hybridization condition.

Here we attempted to synthesize chemically the consensus sequence of human alpha satellite DNA and obtained the results that the synthetic monomer DNA could detect the alphoid repeated centromeric regions of all human chromosomes by fluorescence in situ hybridization.

\section{MATERIALS AND METHODS}

The approach for generating a sequence synthetically for human alpha satellite consensus sequence is illustrated in Fig. 1. Four fragments, F1S, F1A, F2S, F2A ranging in size from 49 to 52 bases were chemically synthesized by automated DNA synthesizer. The DNA was designed to be excised out by EcoRI from the vector. After phosphorylation, $60 \mathrm{ng}$ of each F1S and F2S were annealed with equal amount of F1A and F2A, respectively, to form pairs with complementary regions and subsequently each hybridized fragment was extended with Klenow fragment of $E$. coli DNA polymerase I. The two synthesized, blunt ended fragments were mixed and ligated at SmaI site of pUC118 (purchased from Takara Co., Kyoto, Japan), followed by transformation of $E$. coli MV1304. Transformants were screened by colony hybridization using a 20 -bp oligomer which hybridizes the junction region between F1A and F2S. Five positive clones were obtained. EcoRI digestion of these plasmid DNAs generated 171-bp fragment and the sequence analysis of selected two clones named pAP-1 indicated the expected sequence. With the pAP-1 monomer clone, we subsequently constructed clones containing dimeric and tetrameric consensus units by joining EcoRI and $K p n I$ fragments for dimer designated as pAP-2, and inserting the EcoRI digested pAP-2 into $S p h \mathrm{I}$ site of pAP-2 for tetramer designated as pAP-4.

For Southern blotting, high molecular weight DNA was isolated from human placenta. The DNA was digested with restriction enzymes, separated by agarose gel electrophoresis, and transferred to nitrocellulose filter. The filter was incubated $3 \mathrm{hr}$ at $42^{\circ} \mathrm{C}$ in hybridization solution $(50 \%$ formamide, $5 \times \mathrm{SSC}(0.15 \mathrm{M} \mathrm{NaCl}, 0.015$ 


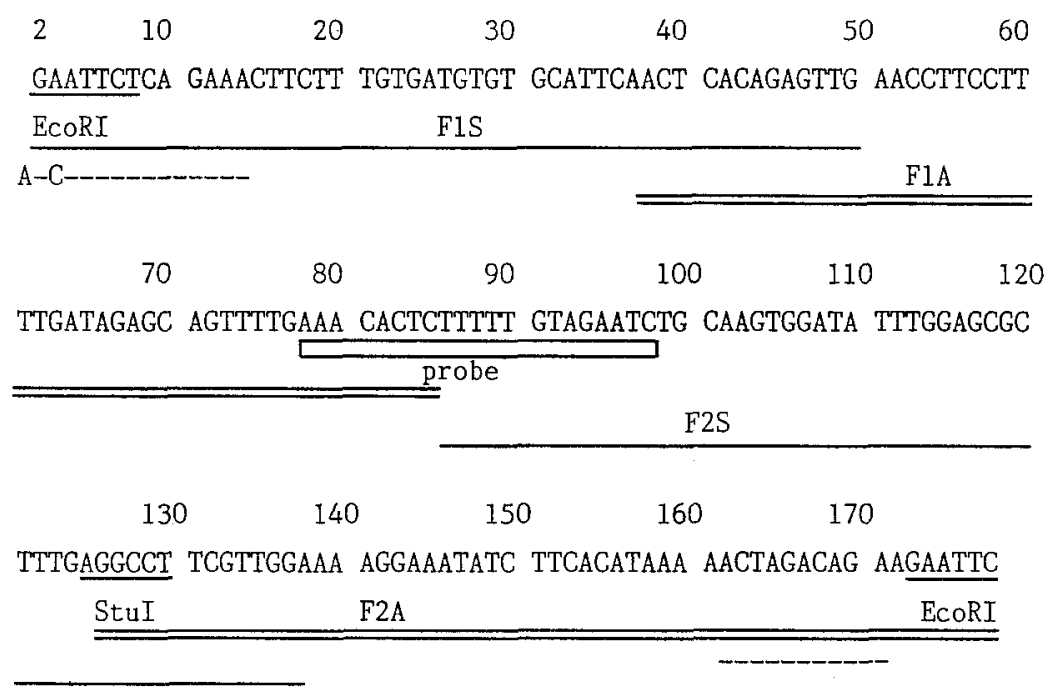

Fig. 1. DNA sequence and synthetic oligonucleotides of the human alpha satellite monomer unit. The monomer unit was assembled from 4 chemically synthesized oligonucleotides which are indicated under the sequence; - 'sense', = 'antisense' strand. The sequence was numbered according to Waye and Willard (1987). These oligonucleotides formed pairs consisting of a 'sense' and 'antisense' strands. Enzymatic extention of fragment pairs by Klenow fragment was used to produce blunt-ended duplexs. Synthetic DNA was designed so as to be excised out by $E c o$ RI for our use later on. The sequence of probe used for screening of the proper ligation was indicated by underline. The base at position 1 was added and the base at position 3 was corrected by site-directed mutagenesis using 5'ACTAGACAGAAAGCATTCTCAGAAA $3^{\prime}$ (that is indicated as broken line) when the construction of dimeric and tetrameric alpha consensus sequences.

M sodium citrate), $0.1 \%$ SDS (sodium dodecyl sulfate), $10 \times$ Denhardt's solution and $100 \mu \mathrm{g}$ denatured salmon sperm DNA per $\mathrm{ml}$ ), and then hybridized for $16 \mathrm{hr}$ at $42^{\circ} \mathrm{C}$ with hybridization solution containing $8 \times 10^{6} \mathrm{dpm}$ per $\mathrm{ml}$ of radioactive $E c o$ RI fragment from pAP-4 $(684 \mathrm{bp})$ under the above condition. After hybridization, the filter was washed at $60^{\circ} \mathrm{C}$ with three 30 min-washes of $0.1 \times \mathrm{SSC}-0.1 \%$ SDS solution. Autoradiography was then performed at room temperature for $3 \mathrm{hr}$.

In situ hybridization was carried out essentially according to Pinkel et al. (1986). Metaphase cells were obtained from EB virus-transformed human lymphocytes. After colcemid arrest in metaphase, the cells were incubated in $75 \mathrm{~mm} \mathrm{KCl}$ for 10 min at $37^{\circ} \mathrm{C}$ and fixed 3 times in $3: 1$ methanol: acetic acid. The cells were spread on microscope slide with dropping. The plasmid pAP-4 DNA was digested with HaeIII and labeled with Photoprobe ${ }^{\text {TM }}$ biotin (Vector Laboratories Inc., USA) according to the manufacturer's directions. The metaphase chromosomes were denatured in $70 \%$ formamide, $2 \times \mathrm{SSC}$ at $70^{\circ} \mathrm{C}$ for $2 \mathrm{~min}$ followed by ethanol series of increasing concentrations $(50,75,95$, and $100 \%)$ at $4^{\circ} \mathrm{C}$. The hybridization mix- 
ture contained $100 \mathrm{ng} / \mathrm{ml}$ biotinylated alphoid monomer, $200 \mu \mathrm{g} / \mathrm{ml}$ sonicated salmon sperm DNA, $10 \%$ dextran sulfate, and $2 \times \mathrm{SSCP}$ (SSC+15 $\mathrm{mm} \mathrm{Na}$ phosphate) in $30 \%$ (or $50 \%$ ) formamide at $\mathrm{pH} 7$. After overnight hybridization at $37^{\circ} \mathrm{C}$, the slides were washed 3 times for $3 \mathrm{~min}$ each in $30 \%$ (or $50 \%$ ) formamide, $2 \times \mathrm{SSC}$ at $42^{\circ} \mathrm{C}$, followed by 3 washes for $3 \mathrm{~min}$ each in $2 \times \mathrm{SSC}$ at $42^{\circ} \mathrm{C}$. The slides were then incubated with anti-biotin rabbit $\mathrm{IgG}$, followed by fluorescinated anti-rabbit IgG goat serum (Cappel, Pa. USA). Finally, the metaphase chromosomes were counterstained with propidium iodide (PI, $0.8 \mu \mathrm{g} / \mathrm{ml}$ ) and diamidinophenylindol (DAPI, $0.4 \mu \mathrm{g} / \mathrm{ml}$ ) to allow simultaneous observation of chromosomes and hybridized probe. The slides were mounted with antifade solution and screened with Nikon fluorescence microscope. The lymphoblastoid cell line No. 2444 is a kind gift from Dr. Nakagome (National Children's Medical Research Center, Japan).

\section{RESULTS AND DISCUSSION}

The consensus sequences of the alpha satellite monomer units were deduced from the sequence data on 153 and 145 cloned monomers (Waye and Willard, 1987; Vissel and Choo, 1987). Since the two reported sequences have differences only in a few bases, we have synthesized DNA fragments based on the report by Waye and Willard (1987) and constructed the alpha satellite monomer unit, subsequently cloned into a pUC vector (Fig. 1). After construction of the monomer unit, plasmids carrying dimeric and tetrameric monomer units were also constructed. The plasmid, pAP-4, containing tetrameric units in tandem was quite stable during the bacterial cell growth and storage in the cell at $-80^{\circ} \mathrm{C}$.

It was reported that the most abundant alphoid sequences form bands of 340 and $680 \mathrm{bp}$ after EcoRI digestion and higher-order repeat units were seen when digested with other restriction enzymes (Willard and Waye, 1987; Alexandrov et al., 1988). So we examined total human DNA by Southern analysis with the synthetic consensus sequence as a probe, Human genomic DNA was digested with EcoRI or BamHI, and subjected to Southern blot analysis using ${ }^{32} \mathrm{P}-\mathrm{labeled} 684-\mathrm{bp}$ EcoRI fragment of pAP-4. The prominent bands were seen at around 340, 680 bp with a less intense bands of $540,870,1,050$, and 2,200 bp in the EcoRI digested DNA under a stringent condition. While prominent bands were seen at around 2,200, 2,600, and 2,800 bp in the BamHI digested DNA (data not shown). The prominent, distinct bands at around 340 and $680 \mathrm{bp}$ may be ascribed to repeated units of alphoid monomer in various chromosome types. Similarly the prominent bands at around $2.0-2.8 \mathrm{~kb}$ may reflect higher-order repeat units dominant in certain chromosome types.

Next, we examined if the chemically synthesized alpha consensus monomer would recognize the alpha satellite DNA at the centromeric region of each chromosome. The DNA of 171 bp consensus monomer was excised from pAP-4 and biotinylated. The DNA was hybridized to metaphase chromosomes as described 


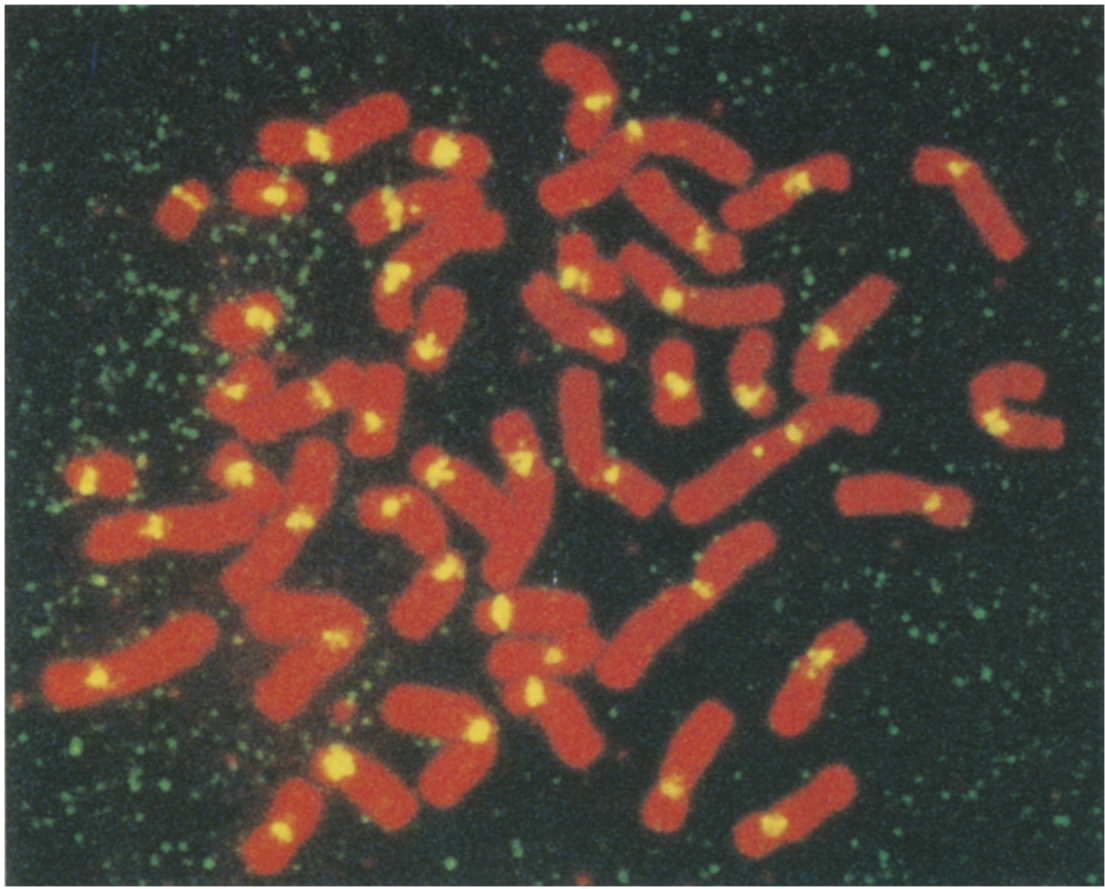

Fig. 2. Fluorescence in situ hybridization with synthetic alpha monomer as a probe to human lymphoblast metaphase spreads. The biotin-labeled probe DNA was hybridized to chromosomal DNA on metaphase spreads as described in MATERIALS AND METHODS. The hybridized probe was detected with FITC-antibodies. FITC (yellow-green) and PI (orange) fluorescences were observed with excitation at $480 \mathrm{~nm}$.
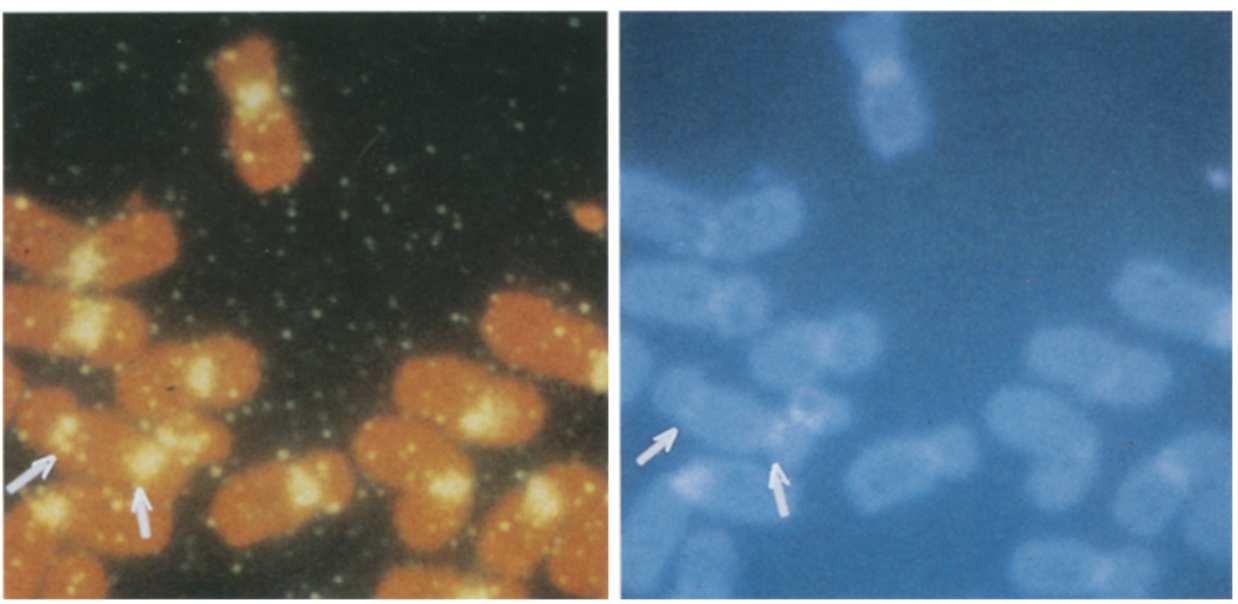

Fig. 3. Fluorescence in situ hybridization with synthetic alpha monomer to human lymphoblast cell line 2444. Left, FITC (yellow-green) and PI (orange) fluorescence; Right, DAPI (blue) fluorescence. Arrows indicate centromeric regions on $\mathrm{X}$ chromosome. 
in MATERIALS AND METHODS. Under a higher stringency condition (50\% formamide at $37^{\circ} \mathrm{C}$ ), intensity of fluorescence varied with chromosomes, and the centromeric region of $\mathrm{Y}$ could not be labeled (data not shown). To ensure that centromeric regions of all chromosome types are stained, we reduced the hybridization stringency; $30 \%$ formamide at $37^{\circ} \mathrm{C}$. Figure 2 shows that all centromeric regions of human chromosomes in a typical metaphase spread were labeled with FITC.

So far, alpha satellite repeat units specific to each human chromosomes type have isolated except for chromosome 2, and 15 (Kidd et al., 1989). Our result suggests that all the centromeric regions of human chromosomes are dominated with a variety of human alphoid sequences, which are recognized by the consensus sequence derived from 153 and 145 monomer units. There has been reported one such ubiquitous, cloned sequence called $\mathrm{p} 82 \mathrm{H}$ detecting all centromeric regions of human chromosomes under a lower hybridization condition. Recently, however, the sequence was shown to be derived from a subfamily of alpha satellite DNA on chromosome 14 (Waye et al., 1988).

In most cases with a constitutional dicentric chromosome, the both centromere regions are stained with $\mathrm{C}$-banding, although only active centromere is stained with Cd-banding (Nakagome et al., 1986). Nakagome et al. reported that in a cell; $46, X$, psu $\operatorname{dic}(X)(q 27)$, case 2444 , the inactive centromere of dicentric X chromosome was not stained even with $\mathrm{C}$-banding. Thus we tried to detect the dicentromeric regions of the $\mathrm{X}$ in metaphase cell of 2444 using the synthetic alphoid monomer probe. As shown in Fig. 3, the synthetic monomer could detect both centromeric regions of the $\mathrm{X}$ chromosome.

The dicentric chromosome is an important parameter in the evaluation of dose, dose-rate or other characteristics of ionizing radiation. The present technique should be useful in the distinction of a dicentric chromosome from that with a twisted arm. Further the probe could be used for detection of other centromere involved chromosome abnormality or heterogeneity (Dale et al., 1989).

In preparation of this paper, we found a similar approach has been tried by Meyne et al. (1989) using a synthetic fragment of consensus monomer unit. However, we experienced that the $171 \mathrm{bp}$ monomer probe gave us a more intense signals compared with $\sim 35 \mathrm{bp}$ fragment probes.

Acknowledgments We wish to thank Dr. Nakagome for the gift of cell line \#2444.

This work was supported in part by a grant from the Foundation for Promotion of Cancer Research backed by Japan Ship-Building Industry Foundation.

\section{REFERENCES}

Alexandrov, I.A., Mitkevich, S.P. and Yurov, Y.B. 1988. The phylogeny of human chromosome specific alpha satellites. Chromosoma 96: 443-453.

Dale, S., Earle, E., Voullaire, L., Rogers, J. and Choo, K.H. 1989. Centromeric alpha satellite DNA amplification and translocation in an unusually large chromosome $14 \mathrm{p}^{+}$variant. Hum. Genet. 82: 154-158. 
Kidd, K.K., Bowcock, A.M., Schmidtke, J., Track, R.K., Ricciuti, F., Hutchings, G., Bale, A., Pearson, P. and Willard, H.F. 1989. Report of the DNA committee and catalogs of cloned and mapped genes and DNA polymorphisms. Cytogenet. Cell Genet. 51: 622-947.

Meyne, J., Littlefield, L.G. and Moyzis, R.K. 1989. Labeling of human centromeres using an alphoid DNA consensus sequence: application to the scoring of chromosome aberrations. Mutation Res. 226: 75-79.

Meyne, J. and Moyzis, R.K. 1989. Human chromosome-specific repetitive DNA probes: targeting in situ hybridization to chromosome 17 with a 42-base-pair alphoid DNA oligomer. Genomics 4: 472-478.

Moyzis, R.K., Albright, K.L., Bartholdi, M.F., Cram, L.S., Deaven, L.L., Hilderbrand, C.E., Joste, N.E., Longmire, J.L., Meyne, J. and Robinson, T.S. 1987. Human chromosome-specific repetitive DNA sequences: novel markers for genetic analysis. Chromosoma 95: 375386.

Nakagome, Y., Nakahori, Y., Mitani, K. and Matsumoto, M. 1986. The loss of centromeric heterochromatin from an inactivated centromere of a dicentric chromosome. Jpn. J. Human Genet. 31: 21-26.

Pinkel, D., Straume, T. and Gray, J.W. 1986. Cytogenetic analysis using quantitative, high-sensitivity, fluorescence hybridization. Proc. Natl. Acad. Sci. U.S.A. 83: 2934-2938.

van Dekken, H. and Bauman, J.G.J. 1988. A new application of in situ hybridization: detection of numerical and structural chromosome aberrations with a combination centromeric-telomeric DNA probe. Cytogenet. Cell Genet. 28: 188-189.

Vissel, B. and Choo, K.H. 1987. Human alpha satellite DNA-consensus sequence and conserved regions. Nucleic Acids Res. 15: 6751-6752.

Waye, J.S., Mitchell, A.R. and Willard, H.F. 1988. Organization and genomic distribution of " $82 \mathrm{H}$ " alpha satellite DNA-evidence for a low-copy or single-copy alphoid domain located on human chromosome 14. Hum. Genet. 78: 27-32.

Waye, J.S. and Willard, H.F. 1987. Nucleotide sequence heterogeneity of alpha satellite repetitive DNA: a survey of alphoid sequences from different human chromosomes. Nucleic Acids Res. 15: 7549-7569.

Willard, H.F. and Waye, J.S. 1987. Chromosome-specific subsets of human alpha satellite DNA: analysis of sequence divergence within and between chromosomal subsets and evidence of an ancestral pentameric repeat. J. Mol. Evol. 25: 207-214. 